\title{
A Brief History of Endophyte Detection Techniques in Grasses
}

\author{
Rana Zaheer Ahmad ${ }^{1}$, Fuad Ameen ${ }^{2,3}$, Rida Khalid ${ }^{4}$, Mousa A. Alghuthaymi ${ }^{5}$, Reem Alsalmi ${ }^{6}$ \& Chunjie $\mathrm{Li}^{1}$ \\ ${ }^{1}$ College of Pastoral Agriculture Science and Technology, Lanzhou University, Lanzhou, China \\ ${ }^{2}$ Department of Botany and Microbiology, College of Science, King Saud University, Riyadh 11451, Saudi \\ Arabia \\ ${ }^{3}$ Department of Marine Biology, College of environmental \& Marine Science, Al-Hodeidah University, \\ Al-Hodeidah, Yemen \\ ${ }^{4}$ University of the Punjab, Lahore, Pakistan \\ ${ }^{5}$ Biology Department, Science and Humanities College, Shaqra University, Saudi Arabia \\ ${ }^{6}$ Biology Department, College of science, Al-Baha University, Saudi Arabia \\ Correspondence: Chunjie Li, College of Pastoral Agriculture Science and Technology, Lanzhou University, \\ Lanzhou, China. Tel: 86-139-1986-1685. E-mail: chunjie@lzu.edu.cn
}

Received: June 3, 2019 Accepted: June 28, 2019 Online Published: July 27, 2019

doi:10.5539/sar.v8n3p66 URL: https://doi.org/10.5539/sar.v8n3p66

\begin{abstract}
Endophytes are the plant mutualists that live asymptomatically inside plant tissue and are found in nearly whole plant kingdom. Endophytic fungi receive shelter and nutrition from host plants and in return provide great advantages to the host. Grasses are a useful forage species and are of great agricultural and socio-economic value. The presence of endophytes in these grasses provide protection, persistence and improved yield against herbivores, insects, pathogens, drought and several other biotic and abiotic stresses. This review summarizes traditional and modern molecular techniques to identify endophytes from turf and forage grasses. Traditional approaches include direct observation, staining, laser micro dissection and pressure catapulting and cultivation-dependent methods that provide a morphological identification of endophytic mycobiota in grass tissues. Earlier studies on endophytes using these methods resulted in several technical implications which molecular approaches are able to solve now-a-days. Molecular approaches include DNA extraction, PCR based DNA Fingerprinting techniques, Denaturing Gradient Gel Electrophoresis, Sanger sequencing, Pyrosequencing, Immunoblot assay, Biosensors, DNA Barcoding and Molecular Phylogenetics etc. A comparison of these detection techniques will facilitate other researchers as well to develop new ways for the detection of endophytes that will contribute to the improvement of grassland in future.
\end{abstract}

Keywords: endophyte, molecular techniques, grassland, fungi, PCR, DNA extraction

\section{Introduction}

Fungal endophytes are the organisms living in a plant for at least a part of its life, without causing any apparent disease. Berry in 1866 was the first scientist who coined the term Endophyte. It refers to any organism occurring within plant tissues, not like the epiphytes that live on plant surfaces. Nevertheless, a lot of them can be detected using staining techniques (Johnson et al., 2006), cultivation based (Siebert and Hugentobler 1987; Fröhlich and Hyde 1999) or cultivation-independent detection methods are used (Gao, Zhou et al., 2005). Moreover, among plant pathogens, fungi and its pathogenic species have well defined thallus comprising of haphae, asexual and sexual reproductive parts Carrolldefined endophytes in another way as mutualists that colonize aerial parts of living plant tissues and do not cause any symptoms of disease, from which pathogenic and mycorrhizal fungi are excluded. As time passed Petrini (1991) proposed an expansion of Carroll's definition to include all organisms inhabiting plant organs that, at some time in their life, can colonies internal plant tissues without causing apparent harm to the host. Therefore, latent pathogens known to live symptomless inside host tissues that have an epiphytic phase in their life cycle are also endophytes. (Bills 1996) told us that endophytes and certain types of mycorrhizae, e.g. Ectendomycorrhizae, Ericoid mycorrhizae and Pseudomycorrhizae, are different. So we can say that mutualistic root inhibited or mycorrhizal fungi that associates themselves with plants and they belong to Ericaceae and Orchidaceae are called as endophytes (Bayman, Lebron et al., 1997). 
Endophytic fungi play a significant role in the survival and ecological behavior of grasses. Different techniques have recently been used for past some years to detect and identify these endophytes and for that purpose, proper processing of grass or plant sample is required (Bills GF. et al., 1996). It depends on the fungal life cycle as well as the endophytic type to choose which technique should be used for better identification and isolation of microbial endophytes. Neotyphodium or Epichloe species are known to colonize mostly cool season grasses and live in a symbiotic relationship (White Jr 1987). In the Epichloe species, only sexual stage structures are present and hyphae are present inter cellularly in host plant with no external disease manifestation. In some grass species, epiphytic growth is observed in Neotyphodium species (Schardl, Leuchtmann et al., 2004). Morphological identification through scraping of seeds, tillers and rhizomes, seed squash method and fragment plating method in tall fescue can be easily observed in the Loliumarundinace and perennial ryegrass L.perenne (Clay 1988).

Some molecular approaches are now used for better species identification of endophytes including PCR, pyrosequencing, DNA fingerprinting and immunoblot assay are also used. (Hiatt, Hill et al., 1999) and Trenton et al., (2007) compared traditional and molecular techniques in seed lots and observed a favorable discrimination. The techniques like restriction fragment length polymorphism (RFLP), gene clone libraries, denaturing and temperature gradient gel electrophoresis(DGGE/TGGE) and next generation sequencing (Wang, Zheng et al.,) technology are widely used to check the microbial diversity (Marzoratiet al.,2008).Although molecular methods are a bit costly than traditional techniques. Traditional techniques need much technical experience as compared to molecular methods. Molecular methods can simultaneously deal with a large number of samples but only a few ones can be treated with using traditional techniques (Trenton et al., 2007). So, both old and new endophyte detection techniques have its own pros and cons. In the future research studies, much effort is going on to develop new ways of detecting fungal endophytes that will in return provide great advantages to the grassland.

\section{Morphological Identification of Endophytic Fungi from Grasses}

Morphological identification deals with the traditional approaches that had been exclusively used in almost all earlier endophyte studies. Identification of endophytic fungi from turf and forage grasses by using traditional techniques include following methods.

\subsection{Direct Observation Method}

In this method, light or electron microscope is used to detect living plant tissues containing endophytic fungal structures. Biotrophic fungi e.g. Phyllacora species, that are unable to grow on standard growth media, can be visualized easily. Most endophytic fungi lack spore producing structures and contain only hyphae, therefore it is not possible to identify fungi to any taxonomic level based on their morphology. This method is not mostly used because endophytic mycobiota can only be visualized but cannot be used as microbial isolate for research purposes (Deckert, Melville et al., 2001).

\subsection{Staining Methods}

Staining methods are well known for the detection of fungal Endophytes in grasslands. Several stains are used like 'Methylene Blue' to deal with morphological characteristics (Moemenet al., 2015). Other stains include 'Cotton Blue' and 'Gentian Violet Blue' followed by Gram's Iodine Solution. The former method is easier to visualize (Clay and Jones 1984). On the other hand, cotton blue can stain only the protoplasm and not able to stain the cell walls (Sampson 1933). For staining of root sections of vesicular arbuscular mycorrhizae, 'Lactophenol Trypan Blue' is mostly used (Sampson 1933). 'Aniline Blue' is also specialized for the staining of mycelium (Bacon, Porter et al., 1977).

This technique is particularly useful in the identification of epiphyllous stages of Neotyphodium species mainly infecting Poaampla (Tadych, Bergen et al., 2007). These staining methods have several drawbacks as they are time consuming, can be hazardous due to the presence of phenol in Lactophenol or cotton blue and can affect the health of researchers. Moreover, during boiling of plant tissues, cell loss can also occur.

Thus, a more rapid, accurate and simple microscopic detection method named 'Rose Bengal Stain' is used which is particularly known for the identification of endophytic mycelia in grasses i.e. perennial eye grass, tall fescue and fine fescue. Rose Bengal stain is better than trypan blue. In addition, this dye is equally better for fresh as well as dry grass samples and gave excellent visual results. For tall fescue, this method of staining is better than the other staining methods as no additional fixing of tissue is required (Jackson and Johnson-Cicalese 1988).

\subsection{Cultivation Dependent Method}

This method also named as 'Fragment Plating Method' has been routinely used for past some years as it is simple, easier and yields large fungal diversity (Arnold, Henk et al., 2007). Most common example of morphological identification using this method is Fagus sylvatica (Unterseher and Schnittler, 2009). It requires a 
series of procedures and morphological identification can be easily done (Wang, Guo et al., 2005). First of all, plant tissue is surface sterilized by thorough washing, then ground properly to isolate internal fungi and cultivate on nutrient agar. Finally, the production of sporulating and none sporulating structures lead to morphological identification. Isolation of endophytic fungi in plant tissues is a critical process and specific incubation conditions depending on plant tissue are required (Hallmann et al., 2006).

\subsection{Laser Micro Dissection and Pressure Catapulting Method}

This method is used to procure specific endophyte from a complex mixture present in a plant tissue. Targeted endophytes are catapulted by using laser beam, having a wavelength in UV or infrared region. Photons of laser beam cut chemical bonds in the tissue allowing endophyte isolation (Balestrini and Bonfante 2008). It is particularly used for grass tissue as reported by (Jahiri 2013) using Calamagrostis phragmitoides, Anthoxanthum nipponicum, Festuca grass samples.

This technique is really a mile stone in the isolation of fungal endophytes direct from tissues as it is used as the first stage to detect species. Fungal hyphae are catapulted and collected in microfuge tubes for further molecular analysis (Kerk, Ceserani et al., 2003) Isolated fungal endophytes are then further used to extract DNA and other molecular techniques for further analysis.

\section{Molecular Identification of Endophytic Fungi from Grasses}

As molecular biology opened new horizons in the field of biology, so study of endophytes became easier and no doubt more precise than traditional techniques. Some molecular techniques are described below.

\subsection{DNA Extraction}

Endophytic fungi can easily be isolated and detected using molecular techniques. For this purpose, it is important to isolate fungal genomic DNA and then purify it through PCR assay. In this extraction method, fresh mycelial mat of endophytic fungi is grown in potato dextrose broth and then transferred on sterile filter paper to obtain genomic DNA by CTAB method. CTAB (cetyl trimethyl ammonium bromide) method is described by (Murray and Thompson 1980). For specific tissue samples, particular DNA extraction protocol is followed. For grass tissues like Bromustomentellus, F. arundinacea, F. pratensis and Loliumperenne, this method is commonly used (Omoumi, Mirlohi et al., 2008).

\subsection{PCR based DNA Fingerprinting Techniques}

Polymerase chain reaction (PCR) method was developed by (Dombrowski, Baldwin et al., 2006) for the detection of Epichloe or Neotyphodium endophytes in tall fescues tissues. This method is sensitive, accurate and specific for the discrimination of one endophytic fungal pathogen from other species in certain turf and forage grasses.Specific fungal universal primers ITS 1 and ITS 4 which give more efficient resolution for at generic or species level andencode ribosomal DNA space genes (Doss, Clement et al., 1998).

\subsubsection{RAPD Analysis}

Randomly amplified polymorphic DNA uses an oligo nucleotide primer against micro staellites present in the gene. Sensitive methods are present particularly sensitive to fungal community (Anderson and Cairney 2004). In a study, Epichloetyphina was isolated from its host grass Bromus erectus. Single bands of randomly amplified DNA from the isolates were cloned and sequenced. Trinucleotide repeat AAG was found as 8-18 repeats and named as micro satellites. Primers are then synthesized corresponding to tandem repeats, PCR done and single band confirm the same genetic locus in all the isolates (Groppe, Sanders et al., 1995).

\subsubsection{RFLP and AFLP Analysis}

RFLP (restriction fragment length polymorphism) detects the length of DNA strands having repeating base pair sequences. Southern blotting using a radioactive probe is then done to analyze DNA. It recognizes repeated sequences by using a specific pattern against these repeats. The major drawback is due to the requirement of large amount of DNA molecule. AFLP (amplified fragment length polymorphism) is a simple, cost effective and faster as compared to RFLP. AFLP has shown well differentiation of Epicoccum isolates than all the other methods (Arenal, Platas et al., 1999).

\subsubsection{SSR Analysis}

SSR are short sequential repeats of DNA in specific areas. It is the most widely used form of DNA fingerprinting. This analysis detects the number of times, these sequences are repeated present on a particular loci of DNA strand. It is relatively cheap, rapid, and easier to perform. In model grass Brachypodiumdistachyon, this analysis is commonly observed (Vogel, J. et al., 2010). In N.lolli $6.3 \%$ and in N. coenophialum 9.7\% unique SSR loci 
was identified from pasture grass. These markers showed much homology with Epichloe species (Van Zijll De Jong, Guthridge et al., 2003). It resembles to RAPD but there are no longer primers are used. So, for getting highly reproducible SSR markers with a property that they should be robust than the RAPD markers used, we use higher annealing temperatures and longer nucleotide primers. (Peever, Ibanez et al., 2002).

\subsection{Denaturing Gradient Gel Electrophoresis}

It is one of the most commonly used molecular methods and is based on the amplified DNA fragments that differ in electrophoretic mobility due to different melting temperatures. This technique is extensively used for characterization and identification of fungal endophytes (Ercolini, 2004).

Polymerase chain reaction along with Denaturing Gradient Gel Electrophoresis (PCR-DGGE) was used broadly as a tool to examine microbial community structure (Lv, Jiang et al., 2017). Firstly, differentiate PCR products by DGGE and find different DGGE bands that shows different taxa, plasmids are prepared by direct cloning of PCR products, cloning of PCR products directly into plasmids and transformed into E. coli DH5a, positive clones are screened for different taxa using DNA fingerprinting techniques. Fungal endophytes in Ammophilaarenaria (marram grass) by using DGGE and nested PCR for 18S r RNA gene were analyzed indicating the reliability of this technique(Kowalchuk, Gerards et al., 1997)

\subsection{DNA Sequencing Methods}

It is not possible to distribute fungi into genera and species based on only the morphological identification. So, DNA sequencing was introduced in endophyte study. The sequences are then deposited in Gene Bank, NCBI and EMBL by using bioinformatic tools (Mehboob-ur-Rahman, Mahmood-ur-Rahman et al., 2016).

\subsubsection{Sanger Sequencing}

It is also known as "dideoxynucleotide sequencing or chain termination method" as in incorporates dideoxynucleotides (ddNTP's) in the growing nucleotide chain leading to chain inhibition. These ddNTP's are labeled and fluorescence detection gives the sequence of the entire DNA. Amplified specific PCR product is cut into fragments, made single stranded and annealed with primers and DNA polymerase add ddNTP's (Sanger, F. et al., 1977).

The genome sequence of wild grass Brachypodium distachyon of Pooideae subfamily is well known and is compared against rice and sorghum genomes sequenced by this method. A precise history of genome evolution was observed across a broad diversity of the grasses (Vogel, J. et al., 2010).

\subsubsection{Pyrosequencing}

It is a modern high-throughput sequencing technique also named as "Sequencing by synthesis" for molecular investigation of fungal endophytes. Small PCR fragments are made single stranded, annealed with an oligonucleotide primer and sequenced. In this method, pyrophosphate is released and light is generated due to luciferin oxidation by luciferase, ATP is also formed. This light is then detected by photodiode (Jumpponen and Jones 2009)

In a study, ITS1-5.8SrRNA-ITS2 sequence is also used for sequencing in the roots and leaves of grass Holcuslanatus (Marquez, S. et al., 2010). There are some salient features of Pyro- sequencing like rapidity, inexpensive along with a free-cloning step and higher production. Due to this reason, it increases 100 times throughput as compared to Sanger sequencing technology (Wang, Zheng et al., 2010). Pyro-sequencing techniques has significant difference in regard of cost, time and throughput of samples.

\subsection{DNA Barcoding}

It is a fast and accurate system of species identification using short specific DNA sequences instead of using whole genome sequence (Begerow, Nilsson et al., 2010). DNA bar code region is very important in intra specific distance with reference to each species. Scientists have reported a variety of fungal DNA gene fragments to determine fungal taxa (Seifert 2009). ITS (internal transcribed spacer) is a universal DNA barcode which shows excellent, successful amplification for all lineages of fungi (Hebert, Cywinska et al., 2003).

In a study, 27 different fungal genera were isolated from roots of these two grasses by using a combination of morphology along with ITS sequence data. Endophytic strains separated from Panicumvigatum which reside in tallgrass showed a wide range of fungal species from a variety of taxonomic order (Ghimire, Charlton et al., 2011). The results showed that endophytes in switch grass shoot tissues comparatively more than root tissues while leaves of Stipagrandis has less endophytes than roots from inner Mongolia china (Su, Guo et al., 2010). 


\subsection{Tissue Print Immunoblot Assay}

It is also known as ELISA (Enzyme Linked Immuno Sorbent Assay), a plate based technique which is used to detect and quantify antibodies, proteins and hormones. Specific endophytic antigen is detected by this method by using specific antibodies that are linked with enzymes responsible for color production on reaction with substrates. Acremonium coenophialum endophyte is detected in tall fescue i.e. Festucaarundinacea by using tissue print immunoblot assay and color is detected at $405 \mathrm{~nm}$ wavelength (Welty, R. 1986). Neotyphodiumlolli antigens in Epichloeovatus is identified by (Miles, di Menna et al., 1998) by using ELISA.

\subsection{Biosensors}

Biosensors are attractive now-a-days for fungal endophyte detection. They can be either DNA based, antibody based or nanoparticles based. Conventional techniques are time consuming, expensive and often need well trained trainers for pre-testing of samples. Biosensors showed such advantages over current analytical methods by expressing intrinsic features like sensitivity, cost effective, rapid detection ability and portability (Ray et al., 2017). A lot of research is going on to develop new biosensors.

\subsection{Molecular Phylogenetics}

A method to build "phylogenetic tree" to identify the taxonomic levels and evolutionary history of any species by using different sequencing tools. Molecular approaches like multiple sequence alignment, Sanger sequencing and DNA barcoding are important in establishing phylogenetic relationships and species identification.(Hettiarachchige, Ekanayake et al., 2015) reported the identification of a novel unclassified perennial rye grass associated endophyte as Putative novel taxon(PNT) on comparison with E.festucae var. lolli and LpTG-2 endophytes using MUSCLE tool. In a study, ten lineages of fescues were analyzed on the basis of their ITS sequences and close phylogeny between Lolium and European Schedonorus and Vulpia and Festucarubra complex (Torrecilla and Catalán 2002).

\section{Conclusions and Future Studies}

Endophytic fungi comprise a diverse group of species existing in various ecosystems. Here, we tried to summarize the study of endophyte detection using different techniques like traditional cultivation method, Laser cutting method and Molecular methods. Instead of large scale applicability of these methods, a vast majority of endophytes still need to be adequately characterize. In the future, DNA bar-coding will be a valuable tool to identify fungal species as it is formally accepted in the Fourth International Barcode of Life Conference. This journey starts from data of fundamental parameters of endophytes and spreads to regional and continental level. Molecular approaches along with phylogenetic analysis play a vital role in species identification. High-throughput sequencing technology can break the ice of fungal ecology. A lot of novel taxonomic categories of fungal endophytes have been discovered and the list is going on.

\section{Acknowledgments}

I would like to say thanks to State key Laboratory of grassland Agro-ecosystems: Key Laboratory of Grassland Livestock industry innovation, Ministry of Agriculture and rural affairs; Engineering Research Centre of Grassland industry, Ministry of Education; College of Pastoral Agriculture Science and Technology, Lanzhou University, Lanzhou 730000, China and Funding was supported by National Basic Research Programme of China (2014CB138702), the Natural Science Foundation of China.(31372366) Program for Changjiang Scholars and innovative Research team in University of China (IRT17R50), Fundamental Research funds for the central universities(LZUJBKY-2018-kb10),111Project (B12002).

\section{References}

Anderson, I. C., \& J. W. Cairney (2004). Diversity and ecology of soil fungal communities: increased understanding through the application of molecular techniques. Environmental microbiology, 6(8), 769-779. https://doi.org/10.1111/j.1462-2920.2004.00675.x

Arenal, F., Platas, G., Martin, J., Salazar, O., \& Peláez, F. (1999). Evaluation of different PCR - based DNA fingerprinting techniques for assessing the genetic variability of isolates of the fungus Epicoccum nigrum. Journal of applied microbiology, 87(6), 898-906. https://doi.org/10.1046/j.1365-2672.1999.00946.x

Arnold, A. E., Henk, D. A., Eells, R. L., Lutzoni, F., \& Vilgalys, R. (2007). Diversity and phylogenetic affinities of foliar fungal endophytes in loblolly pine inferred by culturing and environmental PCR. Mycologia, 99(2), 185-206. https://doi.org/10.1080/15572536.2007.11832578

Balestrini, R., \& Bonfante, P. (2008). Laser microdissection (LM): applications to plant materials. Plant Biosystems, 142(2), 331-336. https://doi.org/10.1080/11263500802150720 
Bary, A. (1866). Morphologie und physiologie der pilze, flechten und myxomyceten, W. Engelmann. https://doi.org/10.5962/bhl.title.120970

Bayman, P., Lebron, L. L., Tremblay, R. L., \& Lodge, D. J. (1997). Variation in endophytic fungi from roots and leaves of Lepanthes (Orchidaceae). The New Phytologist, 135(1), 143-14. https://doi.org/10.1046/j.1469-8137.1997.00618.x

Begerow, D., Nilsson, H., Unterseher, M., \& Maier, W. (2010). Current state and perspectives of fungal DNA barcoding and rapid identification procedures. Applied microbiology and biotechnology, 87(1), 99-108. https://doi.org/10.1007/s00253-010-2585-4

Bills, G. F. (1996). Isolation and analysis of endophytic fungal communities from woody plants. Endophytic fungi in grasses and woody plants, 31-65. https://link.springer.com/article/10.1023/A:1016857917950

Clay, K. (1988). Fungal endophytes of grasses: a defensive mutualism between plants and fungi. Ecology, 69(1), 10-16. https://doi.org/10.2307/1943155

Clay, K., \& Jones, J. (1984). Transmission of Atkinsonella hypoxylon (Clavicipitaceae) by cleistogamous seed of Danthonia spicata (Gramineae). Canadian Journal of Botany, 62(12), 2893-2895. https://doi.org/10.1139/b84-387

Deckert, R. J., Melville, L. H., \& Peterson, R. L. (2001). Structural features of a Lophodermium endophyte during the cryptic life-cycle phase in the foliage of Pinus strobus. Mycological Research, 105(8), 991-997. https://doi.org/10.1016/S0953-7562(08)61957-7

Dombrowski, J. E., Baldwin, J. C., Azevedo, M. D., \& Banowetz, G. M. (2006). A sensitive PCR-based assay to detect Neotyphodium fungi in seed and plant tissue of tall fescue and ryegrass species. Crop Science, 46(3), 1064-1070. https://doi.org/10.2135/cropsci2005.05-0054

Doss, R. P., Clement, S. L., Kuy, S.-R., \& Welty, R. E. (1998). A PCR-based technique for detection of Neotyphodium endophytes in diverse accessions of tall fescue. Plant disease, 82(7), 738-740. https://doi.org/10.1094/PDIS.1998.82.7.738

Gao, X.-X., Zhou, H., Xu, D.-Y., Yu, C.-H., Chen, Y.-Q., \& Qu, L.-H. (2005). High diversity of endophytic fungi from the pharmaceutical plant, Heterosmilax japonica Kunth revealed by cultivation-independent approach. FEMS Microbiology letters, 249(2), 255-266. https://doi.org/10.1016/j.femsle.2005.06.017

Ghimire, S. R., Charlton, N. D., Bell, J. D., Krishnamurthy, Y. L., \& Craven, K. D. (2011). Biodiversity of fungal endophyte communities inhabiting switchgrass (Panicum virgatum L.) growing in the native tallgrass prairie of northern Oklahoma. Fungal Diversity, 47(1), 19-27. https://doi.org/10.1007/s13225-010-0085-6

Groppe, K., Sanders, I., Wiemken, A., \& Boller, T. (1995). A microsatellite marker for studying the ecology and diversity of fungal endophytes (Epichloë spp.) in grasses. Appl. Environ. Microbiol., 61(11), 3943-3949. https://aem.asm.org/content/61/11/3943

Hebert, P. D., Cywinska, A., Ball, S. L., \& Dewaard, J. R. (2003). Biological identifications through DNA barcodes. Proceedings of the Royal Society of London. Series B: Biological Sciences, 270(1512), 313-321. https://doi.org/10.1098/rspb.2002.2218

Hettiarachchige, I. K., Ekanayake, P. N., Mann, R. C., Guthridge, K. M., Sawbridge, T. I., Spangenberg, G. C., \& Forster, J. W. (2015). Phylogenomics of asexual Epichloë fungal endophytes forming associations with perennial ryegrass. BMC evolutionary biology, 15(1), 72. https://doi.org/10.1186/s12862-015-0349-6

Hiatt, E., Hill, N., Bouton, J., \& Stuedemann, J. (1999). Tall fescue endophyte detection: commercial immunoblot test kit compared with microscopic analysis. Crop Science, 39(3), 796-799. https://doi.org/10.2135/cropsci1999.0011183X003900030030x

Jackson, D. S. M., \& Johnson-Cicalese, J. (1988). A rapid staining method for detection of endophytic fungi in turf and forage grasses. Phytopathology, 78, 237-239. https://doi.org/10.1094/Phyto-78-237

Jahiri, X. (2013). Isolation of Fungal Endophytes from Grasses by Laser Micro Dissection and Pressure Catapulting, UiT Norges arktiske universitet. https://hdl.handle.net/10037/5860

Jumpponen, A., \& Jones, K. (2009). Massively parallel 454 sequencing indicates hyperdiverse fungal communities in temperate Quercus macrocarpa phyllosphere. New Phytologist, 184(2), 438-448. https://doi.org/10.1111/j.1469-8137.2009.02990.x

Kerk, N. M., Ceserani, T., Tausta, S. L., Sussex, I. M., \& Nelson, T. M. (2003). Laser capture microdissection of 
cells from plant tissues. Plant physiology, 132(1), 27-35. https://doi.org/10.1104/pp.102.018127

Kowalchuk, G. A., Gerards, S., \& Woldendorp, J. W. (1997). Detection and characterization of fungal infections of Ammophila arenaria (marram grass) roots by denaturing gradient gel electrophoresis of specifically amplified 18s rDNA. Appl. Environ. Microbiol., 63(10), 3858-3865.

Lv, X.-C., Jiang, Y.-J., Liu, J., Guo, W.-L., Liu, Z.-B., Zhang, W., Rao, P.-F., \& Ni, L. (2017). Evaluation of different PCR primers for denaturing gradient gel electrophoresis (DGGE) analysis of fungal community structure in traditional fermentation starters used for Hong Qu glutinous rice wine. International journal of food microbiology, 255, 58-65. https://doi.org/10.1016/j.ijfoodmicro.2017.05.010

Mehboob-ur-Rahman, T. S., M. A. I. Mahmood-ur-Rahman and Y. Zafar (2016). Bioinformatics: a way forward to explore "plant omics". Bioinformatics-Updated Features and Applications, 203. https://doi.org/10.5772/64043

Miles, C. O., Menna, di M. E., Jacobs, S. W., Garthwaite, I., Lane, G. A., ... Ball, O. J.-P. (1998). Endophytic fungi in indigenous Australasian grasses associated with toxicity to livestock. Appl. Environ. Microbiol., 64(2), 601-606.

Murray, M., \& Thompson, W. F. (1980). Rapid isolation of high molecular weight plant DNA. Nucleic acids research, 8(19), 4321-4326. https://doi.org/10.1093/nar/8.19.4321

Omoumi, P., Mirlohi, A., \& Bahar, M. (2008). Detection of lpsA gene in Neotyphodium endophytic fungi of grasses in Iran. Iranian Journal of Biotechnology, 6(1), 1-5.

Peever, T., Ibanez, A., Akimitsu, K., \& Timmer, L. (2002). Worldwide phylogeography of the citrus brown spot pathogen, Alternaria alternata. Phytopathology, 92(7), 794-802. https://doi.org/10.1094/PHYTO.2002.92.7.794

Ray, M., Ray, A., Dash, S., Mishra, A., Achary, K. G., Nayak, S., \& Singh, S. (2017). Fungal disease detection in plants: Traditional assays, novel diagnostic techniques and biosensors. Biosensors and Bioelectronics, 87, 708-723. https://doi.org/10.1016/j.bios.2016.09.032

Schardl, C. L., Leuchtmann, A., \& Spiering, M. J. (2004). Symbioses of grasses with seedborne fungal endophytes. Annu. Rev. Plant Biol., 55, 315-340. https://doi.org/10.1146/annurev.arplant.55.031903.141735

Seifert, K. A. (2009). Progress towards DNA barcoding of fungi. Molecular ecology resources, 9, 83-89. https://doi.org/10.1111/j.1755-0998.2009.02635.x

Su, Y.-Y., Guo, L.-D., \& Hyde, K. D. (2010). Response of endophytic fungi of Stipa grandis to experimental plant function group removal in Inner Mongolia steppe, China. Fungal Diversity, 43(1), 93-101. https://doi.org/10.1007/s13225-010-0040-6

Tadych, M., Bergen, M., Dugan, F. M., \& White, Jr J. F. (2007). Evaluation of the potential role of water in spread of conidia of the Neotyphodium endophyte of Poa ampla. Mycological research, 111(4), 466-472. https://doi.org/10.1016/j.mycres.2007.02.002

Torrecilla, P., \& Catalán, P. (2002). Phylogeny of broad-leaved and fine-leaved Festuca lineages (Poaceae) based on nuclear ITS sequences. Systematic Botany, 27(2), 241-252.

Van Zijll, De J. E., Guthridge, K. M., Spangenberg, G. C., \& Forster, J. W. (2003). Development and characterization of EST-derived simple sequence repeat (SSR) markers for pasture grass endophytes. Genome, 46(2), 277-290. https://doi.org/10.1139/g03-001

Wang, Y., Guo, L.-D., \& Hyde, K. D. (2005). Taxonomic placement of sterile morphotypes of endophytic fungi from Pinus tabulaeformis (Pinaceae) in northeast China based on rDNA sequences. Fungal Diversity.

Wang, Y., Zheng, Z., Liu, S., Zhang, H., Li, E., Guo, L., \& Che, Y. (2010). Oxepinochromenones, furochromenone, and their putative precursors from the endolichenic fungus Coniochaeta sp. Journal of natural products, 73(5), 920-924. https://doi.org/10.1021/np100071z

White, Jr, J. (1987). Widespread distribution of endophytes in the Poaceae. Plant disease (USA), 71, 340-342. https://doi.org/10.1094/PD-71-0340

\section{Copyrights}

Copyright for this article is retained by the author(s), with first publication rights granted to the journal.

This is an open-access article distributed under the terms and conditions of the Creative Commons Attribution license (http://creativecommons.org/licenses/by/3.0/). 